\title{
Women and Elections in Aceh: Islam and Economics Narratives Dominance
}

\author{
Rizkika Lhena Darwin ${ }^{1}$ and Haryanto ${ }^{2}$ \\ \{rizkikadarwin@ar-raniry.ac.id ${ }^{1}$, harymusi@unhas.ac.id² \\ Department of Political Science, Ar-Raniry of State Islamic University, Jl. Syech Abdur Rauf \\ Kopelma Darussalam Banda Aceh, Indonesia ${ }^{1}$, Department of Politics and Government, \\ Hasanuddin University, Jl. Perintis Kemerdekaan KM 10, Makassar, Indonesia²
}

\begin{abstract}
The study of gender equality in election politics addresses structural, cultural, and institutional challenges by establishing a quota mechanism to increase women's participation in the legislature. However, However, all studies did not explicitly explain the problems and strategies used by female candidates. This article tries to fill this gap by analysing female candidates in post-conflict and tsunami areas. The main argument in this paper explains the shifting trends in Acehnese society after the conflict and tsunami that lead to economic and religious narratives used by women candidates in the 2019 general election. Thus, increased pragmatism in society is carried out by social transitions in Aceh after the conflict and tsunami where women politicians tend to make economic and religious issues a bargaining strategy to get out of subordination in the political sphere: women's politics are now increasingly masculine.
\end{abstract}

Keywords: Women, Election, Gender equality, Aceh.

\section{Introduction}

Women's participation in politics is not new; it has been explained in several kinds of literature. Gender equality is also an indicator of the quality of electoral democracy. Either as a politician or candidate or as a broker [1]. The state is also present to encourage women's participation through the implementation of quota mechanisms [2]. Although the quota mechanism does not have much effect on increasing women's representation in parliament, the effectiveness of quotas depends on their design [3]. Hilman [4] added that the implementation of the quota mechanism without the support of press coverage and women's organisations will not achieve maximum results to support the fulfillment of women's representation. In Indonesia, a 30\% quota mechanism for women in political parties has been implemented in each electoral district. In the 2019 elections, of the 14 national parties, there were four parties nominating the most women, namely the Golkar, Demokrat, Nasdem, Gerindra and PDI Perjuangan parties.

Scholars explain that the opportunity to increase women's representation is because of its benefits as an incumbent [5] and is supported by a proportional open-list electoral system model [6]. In addition to the quota mechanism, several articles on women and politics emphasise the challenges and obstacles faced by women, such as structural, cultural and institutional challenges $[2,7,8]$. Structural challenges show that women are not the main economic actors, especially in the family. So that it has limited economic capital to compete in elections. 
Furthermore, institutional challenges, because some party regulations or institutions are not severe in representing and regenerating women.

Moreover, finally, there are cultural challenges, which touch directly with the community as voters and its relation to opportunities to increase women's representation, namely the main role of women as mothers [2]. This is reinforced by the religious narratives used by competitors to use the issue of "women are prohibited from being leaders" so that women are placed in a subordinate position [9].

Some of the studies above have not yet explained how female candidates attempt to counter the subordination of male candidates in the election process, especially for post-conflict and disaster areas such as Aceh. In the 2014 legislative elections in Aceh, there was an increase in participation in the Aceh parliament, from 6\% in the 2009 elections to $15 \%$ in the 2014 elections. Obtaining such chairs is not easy because as an area that implements Islamic Sharia, the domination of Islamic narratives is a challenge amid institutional and structural challenges [10]. The main issue used by the opponents is "Islam forbids women to lead" so that women are placed in a subordinate position.

It is interesting to make Aceh a research locus in this context because Aceh is an area that experienced a long conflict, was hit by the 2004 tsunami disaster and implemented Islamic Law. This paper will explain the issue of campaigning for female candidates in the 2019 elections in Aceh. The argument in this paper would like to explain that the shift in trends in Acehnese society due to the conflict and the tsunami that led to the dominance of economic narratives used by women candidates in the 2019 elections. Economic narratives became the main factor alongside Islamic narratives and even the use of dayah (boarding school) public space as a winning strategy in contestation election. Social shifts caused the increase in community pragmatism in elections in post-conflict and tsunami Aceh, which also influenced an increasingly pragmatic perspective of society. Women politicians then make logistical issues (economic capital) a bargaining strategy and move out of subordination in the political sphere. To be able to explain the arguments above, this paper wants to explain several things. First, what do female candidates use the main issues in mobilising voters? How does he use economic and religious issues? Finally, why is this issue acceptable to the community? What caused the shift in trends from conflict to economic issues to strengthen in post-conflict and tsunami Acehnese society?

\section{Research Method}

The study was conducted in Aceh, taking into account that gender equality efforts vary significantly according to factors in the region, such as religious traditions, culture, levels of democratisation and historical involvement of women in politics in the area. In answering the formulation of the problem, this research will use qualitative methods by considering in-depth data mining of the object of research through in-depth interviews with women and community candidates, as well as literature studies. Key informants are women legislative candidates for the provincial level, namely the Aceh House of Representatives (DPRA), women activists, and the community. 


\section{Result and Discussion}

\subsection{What women campaign for election in Aceh}

Female candidates who contest in the elections must make the most of the opportunity because the opponents will be not only women but also men and party culture which are rooted in society. There are several opportunities for increased participation, including backgrounds as celebrities, businesswomen, party activism and affiliation, family networks, and state-set quotas. From these factors, concludes that the majority of women who are in parliament are business people or have family relations with party leaders or elites [8]. Although the 2019 elections at the national level legislative there were significant changes, from the majority of kinship to the majority party activists. Data reported by Puskapol UI [11], female candidates were elected from party activists as much as $53 \%$ (both with the background of party officials, DPRD members or former regional heads), as many as $41 \%$ due to elements of kinship with the elite, and as many as 6\% were among professional. Whereas the Aceh parliament, Women elected in the 2019 elections at the provincial level legislature consisted of 55.5\% women from involving kinship with the elite and $44.44 \%$ were party activists. The following is the background of the legislative body of women who obtained seats in the 2019 elections in Aceh.

Table 1. Selected female candidates and their backgrounds.

\begin{tabular}{lll}
\hline No & Name & Background \\
\hline 1 & Darwati A Gani & Politician's wife \\
2 & Kartini & Party activist \\
3 & Nurlelawati & Official's Wife \\
4 & Nuraini Maida & Party activist \\
5 & Martini & Party activist \\
6 & Nora Idah Nita & Party activist \\
7 & Suryani & Politician's wife \\
8 & Asmidar & Politician's wife \\
9 & Sartina & Politician's wife \\
Percentage Comparison & $55,5 \%: 44,44 \%$ \\
\hline
\end{tabular}

Women politicians compete with many male candidates, so that background must coincide with campaign issues that are acceptable to society. Because campaigns carried out by women, candidates cannot only emphasise the femininity side, as explained by Dewi [12] explains that the femininity side that is highlighted will have a risk for women in elections, so to compete with men it is essential to bring issues that are not only identical with women. Moreover, the historical dimensions of past conflicts weaken women and put male domination and occur continuously in post-conflict areas; religious narratives weaken women as an agency so that women compete with religious symbols. So, to compete in the contestation of elections, female candidates use economic and religious narratives. Even the conflict issue is left behind even though the people of Aceh quite long experience the historical conflict. The following is the issue of campaigning for female candidates who won seats in the 2019 elections. 
Table 2. Issues on women's candidate campaigns.

\begin{tabular}{|c|c|c|}
\hline No & Name & Background \\
\hline 1 & Darwati A Gani & Creative economy for women, assistance to dayah \\
\hline 2 & Kartini & $\begin{array}{l}\text { Infrastructure, and Creative economic assistance, sewing } \\
\text { training, sports tournaments and sports facilities assistance }\end{array}$ \\
\hline 3 & Nurlelawati & Women's economy, assistance for dayah and surau \\
\hline 4 & Nuraini Maida & $\begin{array}{l}\text { Community economic assistance, assistance to dayahs and } \\
\text { mosques }\end{array}$ \\
\hline 5 & Martini & $\begin{array}{l}\text { Assistance to dayahs, mosque, youth and sports facilities and } \\
\text { infrastructures, implementation of Islamic law }\end{array}$ \\
\hline 6 & Nora Idah Nita & SMEs for women, agricultural equipment and infrastructure \\
\hline 7 & Suryani & Business for women's groups \\
\hline 8 & Asmidar & $\begin{array}{l}\text { Business capital assistance for small traders of mothers, } \\
\text { businesses sewing children's school clothes and other models, } \\
\text { cake businesses, etc. }\end{array}$ \\
\hline 9 & Sartina & $\begin{array}{l}\text { Islamic Sharia, economy through agriculture and home } \\
\text { industry, especially for women }\end{array}$ \\
\hline
\end{tabular}

From the table above illustrates that almost the majority of issues brought by women have economic and Islamic issues (by integrating Islamic education through dayah). Economic issues such as the provision of sewing machine assistance, cake making, livestock assistance, making stringing arts, makeup training and others. From nine elected women legislators, eight women candidates used economic issues specifically. In addition to economic issues, the majority of programs that come into contact with religion are also used by female candidates. The table above explains that five candidates touched on program issues and offered related to religious narratives, especially dayah and surau (mosque) as objects.

After the conflict and tsunami, female candidates used Islamic narratives to counter marginalisation of women through religious narratives that had been carried out by political opponents. Public spaces that are identical to male-dominated have also been accessed by women today, such as dayah, coffee shop and surau [13]. So, the table confirms that female candidates also use dayah as a means and object of the campaign. Such as providing assistance to Dayah or using dayah scholars to help increase its popularity. Even some female candidates who are incumbent use the aspirational funds based on economic and dayah assistance as did Nora Idah Nita, a Democratic candidate from the Women's Party. Nora Idah Nita provides community shovels, traditional fishing gear and agricultural tractors. Besides the results of the interview with Nurlelawati, a female legislative candidate from the Golkar Party said:

I see many problems in the community, especially in my electoral district, namely the districts of Pidie and Pidie Jaya. To help the community, I see that the community feels benefits, so we help Dayah, the community economy and the like. I have served as councillor for two terms, and the 2019 election will be the third term. During the last two periods, I have helped many dayahs and mosques. For example, the majority of my aspiration funds for 2018 are for the construction of dayahs, construction of surau and livable homes. For 2019, my aspirational funds will be directed towards infrastructure development [14].

Added again by Martini, female candidates from the electoral district of East Aceh who said that: 
Attention to this young person is important, so there needs to be a good dayah facility and sports facilities to divert his attention from things that are not good [15].

The strengthening of economic and religious issues, as explained above, has shifted the historical narrative of conflict and peace. Both of these issues were featured in the first postpeace elections in Aceh, namely in the 2006 elections and the 2009 elections, both used by male and female candidates. However, in the 2019 elections, there were no women candidates who used the historical narrative of the conflict, including candidates who were promoted by local parties. Here are the female candidates who won seats in 2019 based on the party that carried them.

Table 3. Selected women candidates and their parties.

\begin{tabular}{llll}
\hline No & Name & Background & Information \\
\hline 1 & Darwati A Gani & Partai Nanggroe Aceh (PNA) & Local Party \\
2 & Kartini & Gerindra & National Party \\
3 & Nurlelawati & Partai Golkar & National Party \\
4 & Nuraini Maida & Partai Golkar & National Party \\
5 & Martini & Partai Aceh (PA) & Local Party \\
6 & Nora Idah Nita & Partai Demokrat & National Party \\
7 & Suryani & Partai Keadilan Sejahtera (PKS) & National Party \\
8 & Asmidar & Partai Aceh (PA) & Local Party \\
9 & Sartina & Partai Golkar & National Party \\
Comparison of National and Local Parties & $6: 3$
\end{tabular}

Table 3 above explains that candidates from local parties such as Aceh Party and Aceh Nanggroe Party no longer use the historical narrative of the conflict as the dominant issue for winning. Although local parties are very identical, they have a connection with the historical conflict in Aceh. Thus, the dominance of economic and religious issues was used by female candidates in the 2019 elections to win votes. Social and economic changes strongly influence this tendency in post-conflict and tsunami communities. However, the extent to which women as agents can manage and have bargained for the realm of religion and economic issues in society. Shifting trend issues into capital and strategies are used by women to fight subordination to open opportunities for women's participation.

\subsection{Women in Aceh post-conflict-tsunami}

Table 3 above explains that candidates from local parties such as Aceh Party and Aceh Nanggroe Party no longer use the historical narrative of the conflict as the dominant issue for winning. Although local parties are very identical, they have a connection with the historical conflict in Aceh. Thus, the dominance of economic and religious issues was used by female candidates in the 2019 elections to win votes. Social and economic changes strongly influence this tendency in post-conflict and tsunami communities. However, the extent to which women as agents can manage and have bargained for the realm of religion and economic issues in society. Shifting trend issues into capital and strategies are used by women to fight subordination to open opportunities for women's participation.

Aceh experienced significant social, economic and political shifts after the conflict and tsunami. It also impacts on the dynamics of issues in elections and opportunities for women's representation. According to Hauser [16], there are three main factors to increase women's representation, namely social, political and economic inclusive. Because of the influence of 
cultural attitudes is a measure for egalitarianism, which has an impact on women's representation opportunities [17]. Five things see Social, economic and political inclusion.

First, post-tsunami economic improvement is more dominant than repair due to conflict conditions. The conflict and tsunami had an impact on the economic life of the people of Aceh [18]. Several NGO organisations that entered Aceh did not want to create a conflict with the Government, so the assistance provided was not related to political issues. Their focus is on disaster relief, and reconstruction rather than the politics of transition to post-conflict communities [19], several actors reported that they were not trained, equipped or mandated to deal with post-conflict. Also, the special assistance program for tsunami victims was allocated at the US \$ 8,000, while for conflict victims, it was allocated at the US \$ 2,500 [19].

Second, women are the target of economic assistance. Conflict and tsunami events shift women as new economic actors. In the past, Aceh was familiar with the matrilineal culture, namely ureung agam mita peng (husband earning money) and ureung inong mita breuh (women looking for rice). Making money is meant by making a living outside the home, even outside the village. Whereas looking for rice is meant by farming. So that women are synonymous with the term "po rumoh" (homeowners) who work together to be the people who manage the house when the husband goes to work. Furthermore, entering the post-tsunami phase, more and more women are becoming single parents supporting their children — the following interviews with communities affected by the conflict and tsunami.

During the conflict, almost the majority of men had to leave the village. So that women in this village become single parents who support their children. I, after the tsunami took my husband's life, I then had to work hard to support my child. I received several economic pieces of training conducted by NGOs [20].

Under these conditions, NGOs target women for economic assistance. As explained by Srimulyani [18], that microfinance (microfinance) is one of the chosen models, especially if the beneficiaries are women or small and medium businesses. The data shows that there are more than one hundred institutions that contribute to the economic empowerment program through microfinance.

Third, the transfer of gender narratives in the form of economic activities. The conflict and tsunami have made Aceh a very open area to be accessed by many people from around the world. Several international institutions entered Aceh, explaining the narrative of gender equality coupled with economic activities. The following interview with the community.

NGOs who came to Aceh after the tsunami usually provided an understanding of gender equality together with economic activities. Like sewing, cooking skills, basically related to improving women's economy. Not political awareness, disaster, etc [21].

In addition to NGOs, the government in transferring gender narratives uses the mechanism of economic activity. The same thing is also explained by Marhaban and Affiat [22], that women's empowerment and capacity building programs touch very little awareness on social issues, political education, conflict management, and practical insights. Aceh has an Inong Balee force that was actively involved in politics in Aceh during the conflict. The following are several programs that entered Aceh after the conflict and tsunami. 
Table 4. Aceh women's program after the conflict and tsunami.

\begin{tabular}{|c|c|c|}
\hline No & Name & Program \\
\hline 1 & Aceh Party & $\begin{array}{l}\text { Supports inong balee in the aisle business (making umbrellas, } \\
\text { decorations, etc.) }\end{array}$ \\
\hline 2 & Multi-Donor Fund (MDF) & $\begin{array}{l}\text { Provision of micro-credit specifically for women, the } \\
\text { fulfilment of women's rights over the issuance of land } \\
\text { certificates }\end{array}$ \\
\hline 3 & USAID-SERASI & $\begin{array}{l}\text { Economic empowerment such as sewing training, social } \\
\text { reconstruction such as issues of pluralism, deradicalisation } \\
\text { and domestic violence, and participatory planning through }\end{array}$ \\
\hline 4 & NGO from Europe & $\begin{array}{l}\text { Training on sewing and supply of the latest sewing machines } \\
\text { in North Aceh }\end{array}$ \\
\hline 5 & UNDP & $\begin{array}{l}\text { In } 2005-2009 \text {, targeted } 20,000 \text { poor households after the } \\
\text { conflict and tsunami, especially those managed by women } \\
\text { with economic achievements and increased income. }\end{array}$ \\
\hline 6 & $\begin{array}{l}\text { Office of Women's } \\
\text { Empowerment and Child } \\
\text { Protection (DPPA) }\end{array}$ & $\begin{array}{l}\text { In } 2015 \text {, targeting the category of women victims of conflict } \\
\text { to be trained to sew was accompanied by spiritual lectures. }\end{array}$ \\
\hline 7 & $\begin{array}{l}\text { Rehabilitation and } \\
\text { Reconstruction Agency } \\
\text { (BRR) }\end{array}$ & Women's cooperatives in several districts/cities \\
\hline 8 & $\begin{array}{l}\text { National Community } \\
\text { Development Program } \\
\text { (PNPM) }\end{array}$ & Savings and loans for women \\
\hline
\end{tabular}

Four, strengthening consumerism and lifestyle after the tsunami. In the aftermath of the tsunami in Aceh, there were international aid organisations that issued $\$ 8$ billion in aid to Aceh in one month and around 3,645 UN-registered NGOs to work in Aceh [19]. In the writings of Mujib and Abdullah (2013) explain that post-conflict and tsunami Aceh shows the process of renegotiating local identities in the practice of commercialisation and consumerism. The arrival of NGOs to Aceh, from one side, had a positive impact on the reconstruction process. However, it also has a negative impact, where every activity is based on the principle of "cash for work", whereas initially, the people of Aceh were powerful with a culture of cooperation and volunteerism. Each time participating in an activity carried out by an $\mathrm{NGO}$, transportation fees will be distributed in return.

Furthermore, the arrival of NGOs also caused the price of goods and commodities to rise in Aceh because some people who worked at NGO institutions received high salaries. In the end, the rising commodity has an impact on the strengthening of consumerism and lifestyle. This has resulted in the strengthening of pragmatism and traction towards the weakening of the principles of kinship, togetherness, solidarity, caring, and even egalitarian [22].

Finally, political inclusion does not coincide with public awareness. Political inclusion that is practised in Indonesia and Aceh, in particular, does not coincide with public awareness in democracy. After the reformation, Indonesia imposed direct and open elections, starting from the presidential, legislative, regional head and village head elections. The direct election in Indonesia does not emphasise the program but the strength of figures (personal) and the exchange of material benefits, such as clientelism, vote-buying, individual gifts, financing services and activities, club goods, pork-barrel projects [23]. Strengthening transactional politics along with weak awareness and rationality of the community will cause economic logic to influence the logic of campaigns used by women candidates. 
Some of the reasons above can explain that political inclusiveness without awareness together with social inclusion that is increasingly pragmatically oriented towards economic benefits is causing the dominance of campaign issues to be used today. It can be said that the shifting trend towards consumerism along with transactional political inclusive, will strengthen the strengthening of pragmatism which has a short-term impact.

Thus, the dominance of economic and religious issues was used by female candidates in the 2019 elections to win votes. Social, economic and political changes strongly influence this tendency in post-conflict and tsunami societies. Furthermore, the extent to which women as agents can manage and have bargained for the realm of religion and economic issues in society. This shift in trend will be significantly influenced by the combination of capitalism and Islamic narratives after the conflict and tsunami. Then push the shift of issue trends into capital and strategies used by women to fight subordination to open up opportunities for women's participation.

\section{Conclusion}

The conflict and tsunami experienced by the people of Aceh resulted in the political orientation of the people of Aceh. Historical narratives of conflict, religion (which strengthens subordination) and traditionalism (strengthening of patriarchic culture) become capitalist (economic) and pragmatic. The shift in orientation affects voter preferences and re-reads subordination and even the way women candidates fight subordination in political contestation. After the conflict and tsunami, women have resembled men in using public space and economic issues even using money politics. Social shifts caused the increase in community pragmatism in elections in post-conflict and tsunami Aceh, which also contributed to an increasingly pragmatic perspective of the people.

\section{References}

[1] Darwin. R.K.:The power of female brokers: Local elections in North Aceh. Contemporary Southeast Asia, Vol. 39.pp. 532-551 (2017)

[2] Delys S. Women and political representation: Handbook on increasing women's political participation in Georgia (Georgia: EMC) (2014)

[3] Schwindt-Bayer L.A.: Making quotas work: The effect of gender quota laws on the election of women. Legislative Studies Quarterly, Vol. 34.pp. 5-28 (2009)

[4] Hillman.: Increasing women's parliamentary representation and the pacific: The Indonesian experience, Asia and the Pacific Studies, Vol. 4.pp. 38-49 (2017)

[5] Shair-Rosenfiled.S. The alternative incumbency effect: Electing women legislators in Indonesia Electoral Studies, Vol. 31.pp. 576-587 (2012)

[6] Dettman, T. Pepinsky, and J. Pierskalla.: Incumbency advantage and candidate characteristics in open-list proportional representation systems: Evidence from Indonesia, Electoral Studies, Vol. 6.pp. 1-34 (2017)

[7] Wahyuningroem. S.L.: Meningkatkan partisipasi perempuan dalam politik di Aceh: tantangan dan peluang (Banda Aceh: UNIFEM) (2008)

[8] Berg. L.: Women's pathways into parliament: The case of Indonesia MIDM19 20151 (2019)

[9] Badruddin s, P. Halim, and Z. Hamson, "Voters perception on gender equity in public elections in Makassar city, Indonesia, International Journal of Scientific Development and Research, Vol. 2.pp. 31-35 (2017) 
[10] Nurlinah, R.L. Darwin, and Haryanto.: After shari'ah: Islamism and electoral dynamics at local level in Indonesia Global Journal Al Thaqafah, Vol. 8.pp. 17-29 (2018)

[11] Kompas.: Puskapol UI: Caleg perempuan terpilih DPR didominasi aktivis parpol (2019)

[12] Dewi K.H..: Gender risk and femininity: Personal branding of female politicians in the strong political dynasty feature of South Sulawesi, Jurnal Studi Pemerintahan, Vol. 9.pp. 533-588 (2018)

[13] Darwin R.K..: Bireuen Aceh: The Aftermath of Post-conflict Politics and the Decline of Partai Aceh," in Electoral Dynamics in Indonesia: Money Politics, Patronage and Clientelism at the Grassroots, E. Aspinal and M. Sukmajati, (Singapore: NUS Press).pp. 39-53 (2019)

[14] Interview, Banda Aceh, August 1 (2019)

[15] Interview, Martini, East Aceh, April 7 (2019)

[16] Hauser. C.E. : Gender equality in Southeast Asia: A comparative study of Indonesia and the Philippines Thesis, Naval Postgraduate School Monterey California (2017)

[17] Norris P.: Women's legislative participation in Western Europe West European Politics, Vol. 8, no. 4, pp.90-101 (1985)

[18] Srimulyani E..: Women, micro-finance and income generation rafter the political conflict and the tsunami in Aceh,. Asian Journal of Women's Studies, Vol. 19.pp. 93-112 (2013)

[19] Koo K.L.Gender at the crossroad of conflict: Tsunami and peace in post-2005 Aceh," Feminist Review, Vol. 101.pp. 59-77 (2012)

[20] Interview, August 8 2019, Banda Aceh (2019)

[21] S. Marhaban, and R.A. Affiat:: Habis Senjata Terbitlah Mesin Jahit: Perempuan Kombatan dan Senjakala Gerakan Perlawabab Muslim Bersenjata (2018)

[22] I. Mujib, and I. Abdullah.: Kuasa pasar dalam pembentukan identitas Aceh: Renegosiasi identitas lokal dalam praktik komersialisasi dan konsumerisme pasca konflik dan tsunami di Banda Aceh," Jurnal Pemikiran Sosiologi, Vol. 2.pp. 59-70 (2013)

[23] Haryanto.: Adaptation and continuities in clientelism in a fishing community in Takalar, South Sulawesi. Contemporary Southeast Asia, Vol. 39.pp. 511-531 (2017) 